\title{
Land Management Practices and the Yield of Cassava (Manihot esculenta Crantz) in the Humid Deltaic Tropical Environment of Nigeria
}

\author{
Mmom PC, Ezekwe IC and Chukwu-Okeah GO* \\ Department of Geography and Environmental Management, University of Port Harcourt, Nigeria
}

Submission: June 29, 2016; Published: July 21, 2017

"Corresponding author: Chukwu-Okeah GO, Department of Geography and Environmental Management, University of Port Harcourt, Nigeria, Email: giftchukwuokeah@yahoo.com

\begin{abstract}
The practice of the adoption of different land management systems in the growth of crops have overtime affected the level of crop production in Nigeria, this is because land management system practice determines the amount of nutrient that will either be retained in the soil or loss from the soil. This study was poised to assess the potency of three land management systems in the yield of cassava as a test crop. This was done using the Traditional, (planting on the surface), Ridge and the Mound land management system. To achieve this runoff plots were constructed with the size $(5 \mathrm{~m} \mathrm{x} 10 \mathrm{~m})$ and fertilizer applied to the three treatment plots. The result of the study revealed that the ridge land management system had the highest yield accounting for 156 tubers of cassava which in turn amounts to 35.8t/ha as against the other two land management systems. The study therefore recommended that the ridge land management system should be adopted as a land management practice to increase cassava production which in recent time a foreign earner and for increased production.
\end{abstract}

Keywords: Land management systems; Crop yield; cassava

\section{Introduction}

The drive for the actualization of food for all have over the years has never been met; this is because successive Government comes with its own agenda which has not concentrated effort on the need for food production through agricultural investments. Food production is not given its rightful place both in budgetary allocation and in planning; hence most African nations are faced with this overwhelming challenge of meeting the food needs of its ever growing population.

In Nigeria, a good proportion of its population depends wholly on cassava as their major type of food, which is prepared in different forms as special delicacies for special events. Cassava has been observed also to play significant role in the generation of foreign exchange which therefore increased the concerns for this tuber crop.

Within the tropical regions, it is seen to provide both essential nutrients required by man for growth and energy, and as a source of income. Basically in Africa, the international fund for Agricultural development (2013) has it that about 600 million persons depend on cassava, although it is still been produced by local farmers, with the use of crude implements. A good number of the farmers practice agriculture at subsistence level, hence producing cassava only for their homes and little for the market. Only about $5 \%$ of the total cassava production is used in the industry as raw materials [1].

Cassava provides about $80 \%$ of the total energy intake of many Nigerians [1]. As a food crop, cassava fits well into the farming systems of the smallholder farmers in Nigeria because it is available all year round, thus ensuring household food security. Compared to grains, cassava is more tolerant to low soil fertility and more resistant to drought, pests and diseases [2].

Cassava is a staple food in this part of the world; therefore every single home depends on it as a source of food. Importantly, the variety of delicacies by which it is prepared gives this tuber crop a significant place in the economy of the people. More so, the need for cassava globally has increased since it is now a foreign earner. 
The practice of land management is purely an activity that is concerned with the application of forces to alter the natural soil condition for the purposes of agriculture [3]. Land Management Systems that increase crop yield and the stability of the ecosystem by reducing soil degradation have been termed to be appropriate since there help in the conservation of the natural resource base for increased production (Lal, 1985) as cited in Omenihu et al. [4].

In a study carried out by Omenihu et al. [4] on the effect of Land Management Practices on some Soil Properties and Field Performance of Cassava-Maize Intercrop in Umudike, Southeastern Nigeria. Using five land management systems such as were fallow-grazing cropping (FGC), traditional farming (TF), no-tillage (NT), minimum tillage (MT) and conventional tillage (CT) for a study period of four years. The study revealed that fresh tuber yield of cassava was higher under CT and MT management practices than NT. This observation emphasizes the importance of good seedbed preparation which is different for grain and tuber crops.

According to Bamire \& Amujegbe [5] Yam and cassava are the two most important root and tuber crops grown for food in West and central Africa. It is observed that the basis for the Nigeria's food security programme is to enhance agricultural production to meet the food self-sufficiency agenda.

Bamire \& Amujegbe [5] emphasized that the type of land management technique adopted by farmers have a relationship with the produce of the farm and the income of farm operators, as well as the effective, efficient and sustainable use of the land as a resource.

Bello [6] emphasized the need of an effective land management system to help in improving soil fertility by maintaining the crop residue so as to improve the supply of organic material and which finally will result into high increase in food production. He further explained that cropping systems which is the way in which crops are arranged on the land, plays an important role in the production process of the crop. Hence the need for a sustainable land management system for increased crop production.

Akyea [7] examined the role of different land preparation methods on nutrient loss and cassava yield in Kumasi Ghana and concluded that land management systems influences cassava yield. The result of the study showed that cassava yield ranged between 25.01, 28.01 and 28.65t/ha. Ridging across slope was identified as having the highest yield of 28.65tonnes/ha followed by planting on the flat, and zero tillage.

However, studies aimed at assessing the impact of different land management systems in relation to cassava cultivation have not received the required attention in the area in literature owing to the importance of this crop. Hence this study is poised to ascertain the extent of cassava production amidst different land management systems as well as to identify the level of cassava production in a humid tropical deltaic environment due to the fragile nature of the environment.

\section{Study Area/Experimental Site}

The study experimental site was in established in Mgbueto community in Emohua local Government area of Rivers State. Emohua by its geography is located at latitude $6^{\circ} 43^{\prime} 30^{\prime \prime}$ and $6^{\circ}$ $54^{\prime} 0^{\prime \prime} \mathrm{E}$ and $4^{\circ} 50^{\prime} 0^{\prime \prime}$ and $5^{\circ} 10^{\prime} 0^{\prime \prime} \mathrm{N}$. Emohua is situated coastal plain sands of the old eastern Niger Delta. Its geology is of fluvial sediments. Emohua topographically is very unique and it is located within the coastal plains which by its structure are of the sedimentary rocks of the Agbada, Akata and Benin formation of the Niger Delta. Its height falls within $10 \mathrm{~m}-25 \mathrm{~m}$ above sea level [8].

Emohua belongs to the Coastal Sand ridges zone of Rivers state. The area is drained by two major rivers, the New Calabar River and the Sombreiro River which extends towards the southern flank of Ndele community and Abua/Odua local Government area, where there exist a confluence. The drainage network pattern in the area does not fit into the conventional dendritic or trellised pattern of drainage. The area experiences poor drainage, this is because of its low lying state and the abundance of surface water accompanied by excessive rainfall of about $2476 \mathrm{~mm}$. The soils in Emohua are made up of sandybarns, humus, alluvium and the outer belt of salt water swamps, clay and mud.

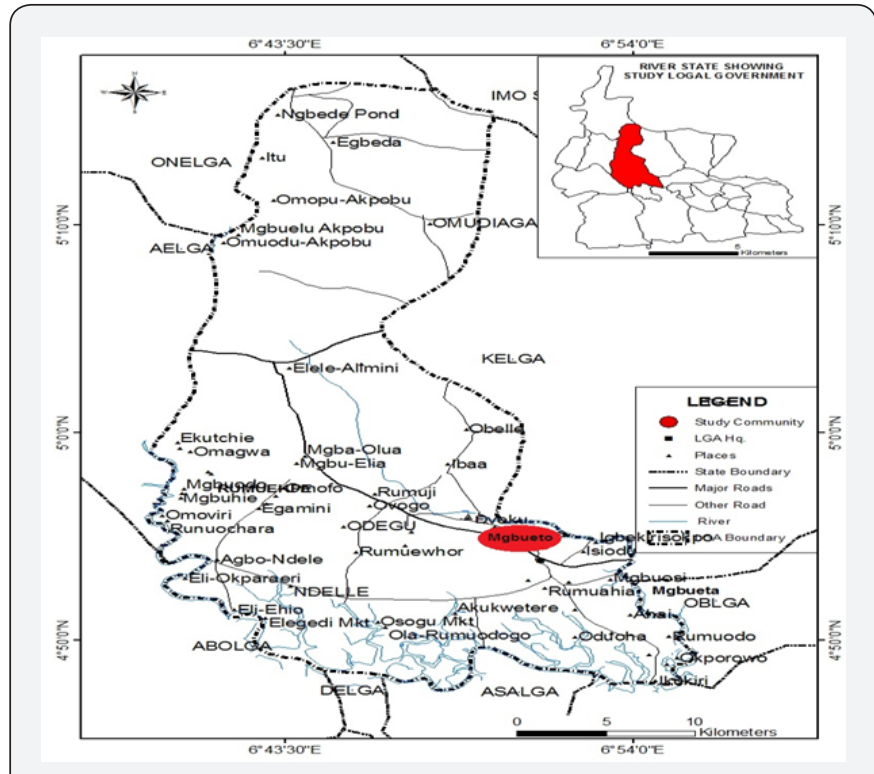

Figure 1: Emohua L.G.A showing Experimental site.

The soils are in rich in phosphorus because of the nutrients from the parent materials. Emohua area has the same weather condition like Port Harcourt as a region. The climatic condition is the humid tropical climate [9]. Emohua according to Efe \& Weli [10] is located within the humid tropics. In most months of the 
year, there is significant rainfall in Emohua. The area experiences a short dry season which is not very significant. The average annual temperature in Emohua is $26.5^{\circ} \mathrm{C}$ Figure 1 [11].

\section{Materials and Methods}

In other to achieve the objective of the study, runoff plots were constructed. Three runoff plots were constructed with each measuring $(10 \mathrm{~m} \times 5 \mathrm{~m})$ on a slope of $0.2199^{\circ}$. Each runoff plot was constructed with corrugated aluminum sheets which were buttressed by wood bars on either side of the whole plot to delineate the runoff collection area. The aluminum sheets were sunk to the ground to a depth $5 \mathrm{~cm}$ to ensure that runoff and sediments do not enter into another plot. The land management systems that were adopted for the study are;

\section{The traditional land management system (planting on the surface)}

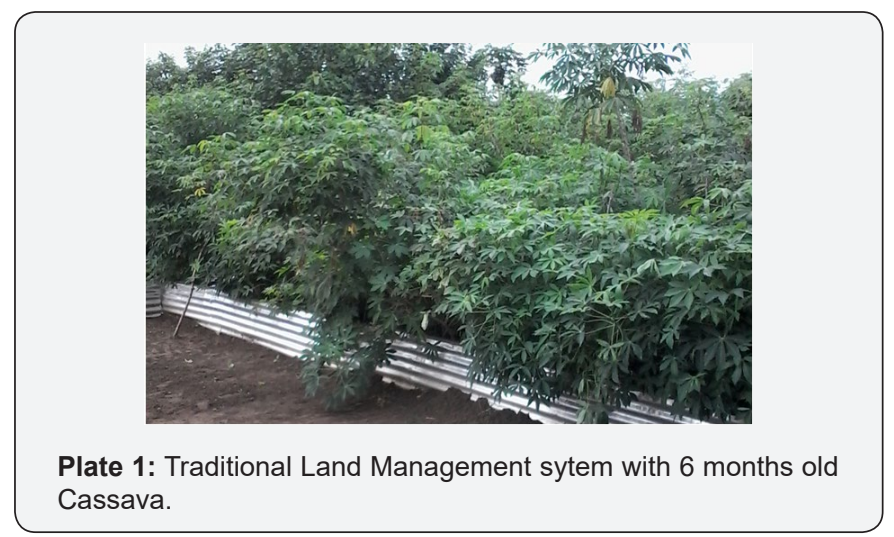

The traditional land management plot, (Plate 1) which in principle is planting on the surface. The term traditional as used in this study implies that this method is the traditional land management system being practiced by farmers in the study area.

\section{The ridge land management system}

Ridge land management system, ridges were made with height of $28 \mathrm{~cm}$ and $30.4 \mathrm{~cm}$ apart from one another. Plots were cleared of weeds twice within the period of the study.

\section{The mound land management system}

Mound land management system, mounds were constructed with the height of the mounds measuring $28-30 \mathrm{~cm}$ high and a circle diameter of about $24-36 \mathrm{~cm}$. weeding was also done twice throughout the period of the study.

In each of the runoff plot was planted cassava and observed for a period of 12 calendar months. Fertilizer as a nutrient booster was administered to cassava in the different land management systems. This was done using the band method which entails applying the fertilizer $100 \mathrm{~cm}$ around the cassava, with a fertilizer rate of $45 \mathrm{~kg}$ across the different land management systems. The fertilizer was administered immediately after the first weeding of grasses around the crops. The NPK 15, 15, 15 fertilizer was used. The essence was to identify the characteristics of the different land management systems in terms of crop yield (Plate 1-3) (Figure 2).

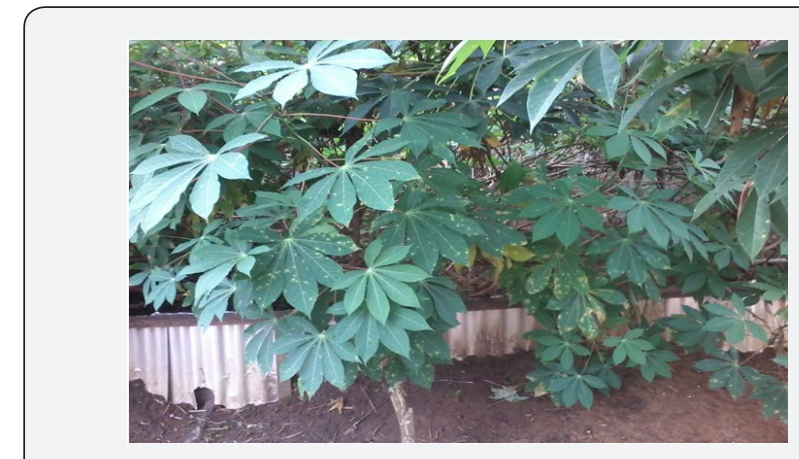

Plate 2: Ridge Land Management sytem with 6 months old Cassava.

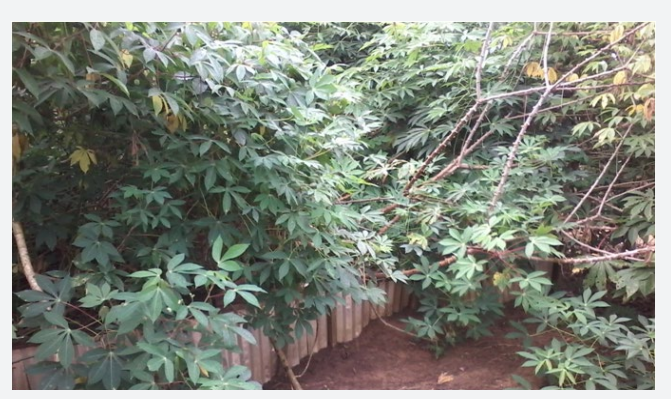

Plate 3: Mound Land Management sytem with 6 months old Cassava.

To determine the slope of the area, the digital elevation model (DEM) of the area was used and this deduced that the experimental site for the study was on a low land with an average slope of $0.2199^{\circ}$ (see Figure 2 below).

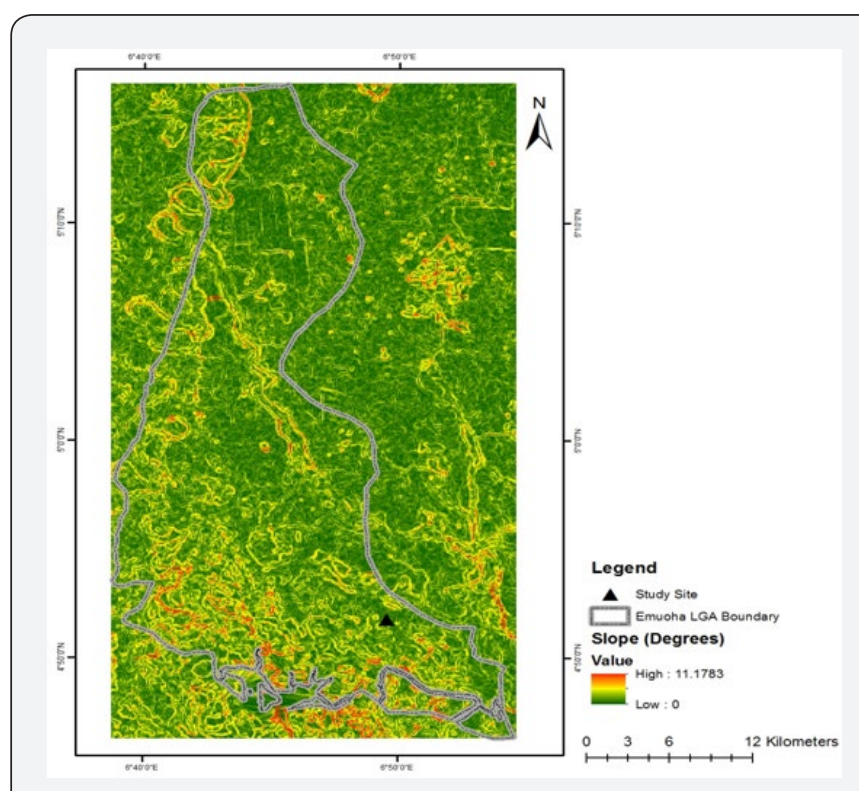

Figure 2: Digital Elevation Model showing Slope of study site. 


\section{Agricultural Research \& Technology: Open Access Journal}

\section{Results and Discussion}

In this study cassava as crop was used as the experimental crop, which was planted in the traditional, ridge and mound land management systems. The result of the yield from the different land management systems revealed that cassava yield from the traditional land management system was a total of 92 tubers which was harvested from the traditional land management plot. This accounted for a total of 25.6t/ha (Plate 4-6) (Table 1 \& Figure 3).

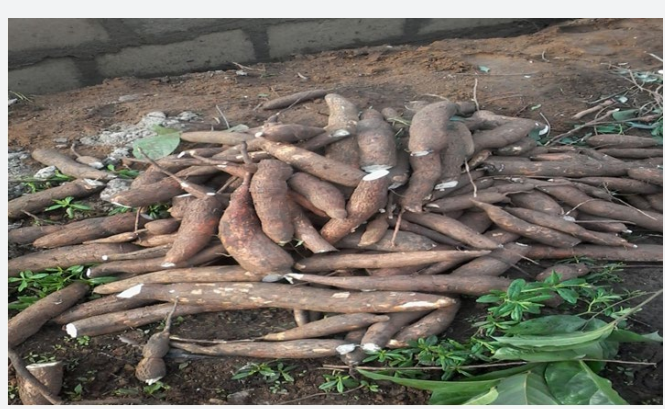

Plate 4: Cassava yield from the traditional land management system.

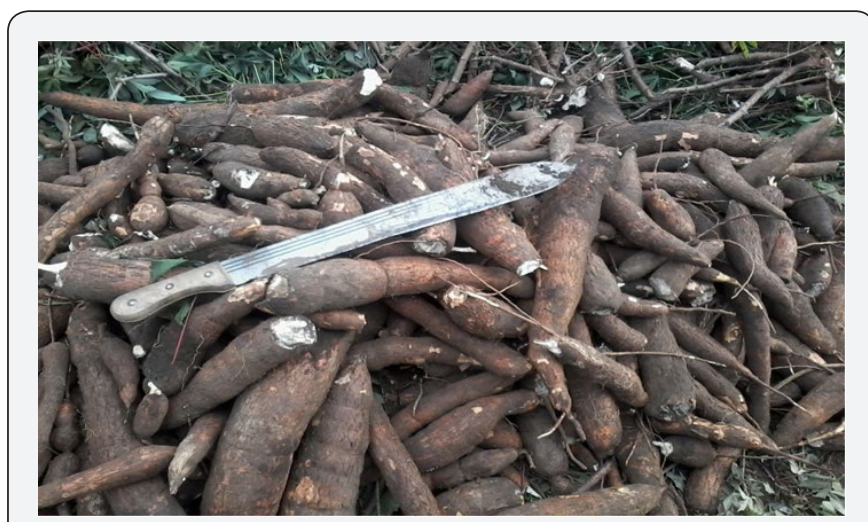

Plate 5: Cassava yield from the ridge land management system. Lastly, the mound land management system as observed had a total of 112 cassava tubers, this therefore accounted for $25.4 \mathrm{t} /$ ha.

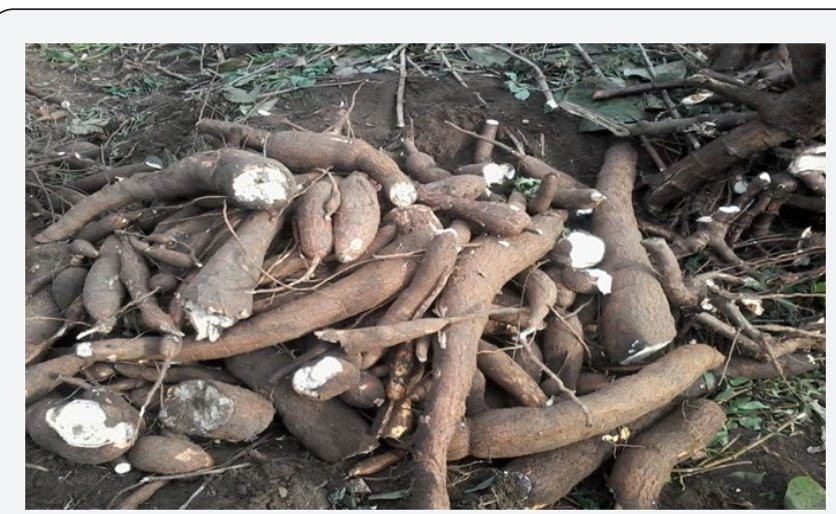

Plate 6: Cassava yield from the Mounds land management system.
Table 1: Cassava Yield from the different Land Management Systems.

\begin{tabular}{|c|c|c|}
\hline Land Management Systems & Quantity & Weight t/ha \\
\hline Traditional & 92 & 21.6 \\
\hline Ridge & 156 & 35.8 \\
\hline Mound & 112 & 25.4 \\
\hline
\end{tabular}

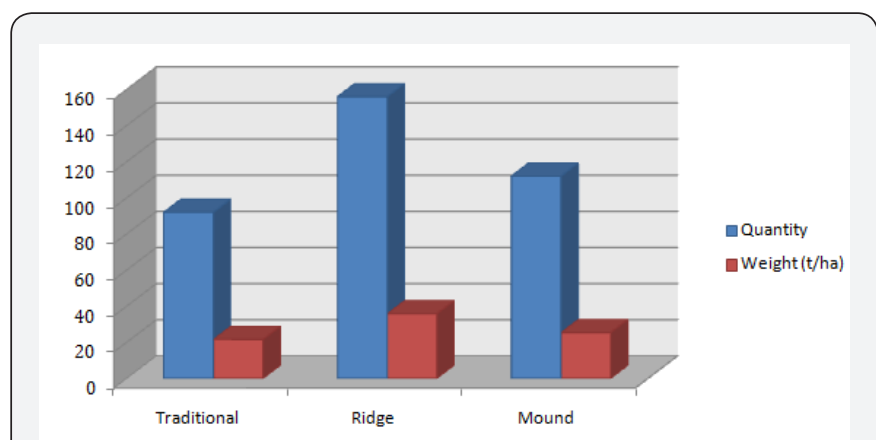

Figure 3: Cassava Yield distribution in the Different Land management Systems.

\section{Conclusion and Recommendation}

The swamp forest Agro-ecological zone of Nigeria, of which the study area is part of has over the years practiced different land management system targeted at improving crop productivity to meet the food need of the ever growing population.

As revealed by the study, the most effective land management system in the soil enhancement is the ridge land management system, this therefore implies that the practice is the most suitable in the control of erosion which reduces nutrient in soil and hence will enhance agricultural production.

Cassava yield from the different land management systems as observed showed that the ridge land management system had the highest cassava yield as it accounted for 35.8tonnes/ ha, while the traditional and mounds land management systems accounted for 21.6tonnes /ha and 25.4tonnes/ha respectively. This findings agrees with Akyea [7] and Omenihu et al. [4]. This showed that the ridge land management system amongst others has the capacity to reduce nutrient loss and enhance production of cassava in the humid deltaic tropical environment.

It goes further to suggest that it also has the capacity for increased production. The ridge land management system has also proved potency in soil nutrient conservation and hence can be used on a large scale to increase cassava production to meet the ever increasing need of the growing population.

The study concluded that ridging as a land management system is the most suitable land management system for cropping with emphasis on cassava, this is because its ability to conserve soil, nutrients and water is effective and efficient, hence leads to higher crop yield than the other land management systems used in the study, therefore should be adopted as a land 
management practice to increase cassava production which in recent time a foreign earner.

\section{References}

1. Ani SO, Ikechi KA, lioyd JS (2013) Processing and Marketing of selected Cassava Products in South-east Nigeria. J Economics 4(2): 105-111.

2. Obisesan AA (2013) Credit accessibility and poverty among small holdecassava farming households in southwest Nigeria. Greener Journal of Agricultural Sciences 3(2): 120-127.

3. Afolayan SO, Babalola O, Igbeka JC (2005) Tillage systems and their effect on some soil properties, crop growth and shoot yield of grainamaranth. AMA. Agricultural Mechanization in AsiaAfrica and Latin America 36: 46-51.

4. Omenihu AA, Opara-Nadi OA, Kamalu OJ (2014) Effect of Land Management Practices on Some Soil Properties and Field Performance of Cassava-Maize Intercrop in Umudike, Southeastern Nigeria. Proceedings of the International Soil Tillage Research Organisation (ISTRO), Nigeria Symposium, Akure, Nigeria.

5. Bamire AS, Amujoyegbe JB (2006) Economic Analysis of Land
Improvement Techniques in Smallholder Yam-Based Production Systems in the Agro-ecological Zones of Southwestern Nigeria. Hum J Ecol 18(1): 1-12.

6. Bello WB (2008) Environmental Sustainability of Some Cropping Systems in the Humid Tropics. African Research Review 2(3): 262-277.

7. Akyea AO (2009) The effect of different land preparation methods on erosion and growth yield of cassava. An unpublished PhD dissertation. Kwame Nkrumah University of Science and Technology. Kumasi Ghana.

8. Oyegun CU (1999) Geology in Port Harcourt Region. In: Oyegun CU, Adeyemo A (Eds), Paragraphics Port Harcourt, Nigeria.

9. Osuiwu BO, Ologunorisa TE (1999) Weather and Climate in Port Harcourt Region. In: Oyegun CU, Adeyemo A (Eds), Paragraphics Port Harcourt, Nigeria, p. 303.

10. Efe SI, Weli VE (2015) Economic Impact of Climate Change in Port Harcourt, Nigeria. Open Journal of Social Sciences 3: 57-68.

11. International Fund for Agricultural Development (2013) Cassava: Turning a Subsistence Crop into a Cash Crop in Western and Central Africa, Rural Poverty Portal, Breadcrumbs Portlet, Powered by IFAD.

\section{Your next submission with Juniper Publishers will reach you the below assets}

- Quality Editorial service

- Swift Peer Review

- Reprints availability

- E-prints Service

- Manuscript Podcast for convenient understanding

- Global attainment for your research

- Manuscript accessibility in different formats

( Pdf, E-pub, Full Text, Audio)

- Unceasing customer service

Track the below URL for one-step submission https://juniperpublishers.com/online-submission.php 